\title{
Setters to the Editor
}

Dear Gary,

I was pleased to read "Guts and Grasses" by Ned Snyder. It is interesting that he is a non-traditional rangeland researcher. This is the first article I can remember that gave some credit to Allan Savory's Holistic Management principles, processes, and practices.

Also interesting to me is the Holechek paper, “Grazing Impacts on Rangeland Vegetation: What We Have Learned.” They mention how much has been learned in the last 20 years. Where have they been?

Savory understood and taught the impacts of livestock grazing and the negative effects of long-term exclusion and set stocking in brittle environments 30 years ago!

Many of the ranch operators I have read about, that receive awards for excellent stewardship, have been exposed to and practice Holistic Management.

I am a long-time member of SRM in California and I am also a Holistic Management Certified Educator. I met Allan Savory in 1978 when we both spoke at Dr Ensminger's Stockmans' School. (After 2 days all sessions closed and all attended Savory's presentation.)

I attended several of Savory's schools, realized that what he taught fit my experience and observations, and started teaching Holistic Management in my Extension Workshops.

I did receive the Rangeland Manager Award from the California Section of SRM, partly for conducting these workshops, but could not convince the SRM leaders to consider Savory as a source of valuable information.

At that time UC Berkeley researchers (Heady et al) were studying vegetation response to simulated grazing by clipping small plots and adding straw for residual dry matter. They concluded that residual dry matter and weather pattern determined species composition and that grazing management had little effect. They had randomized and replicated plots, but the treatments were artificial and did not reflect reality.

There! I got that off my chest. I now do international livestock consulting and find Holistic Management principles, processes, and practices are very appropriate, useful, and accepted in the developing countries as well as in the United States.

Best regards,

Monte Bell

UC Cooperative Extension, Emeritus

Holistic Management Certified Educator

International Livestock Consultant

mbel195963@yahoo.com 